\title{
Small-strain stiffness degradation of artificially cemented sands
}

DOI:

10.1680/jgele.19.00021

\section{Document Version}

Accepted author manuscript

Link to publication record in Manchester Research Explorer

\section{Citation for published version (APA):}

Mendoza-Ulloa, J. A., Lombardi, D., \& Syed, A. S. M. (2020). Small-strain stiffness degradation of artificially cemented sands. Geotechnique Letters, 10(2). https://doi.org/10.1680/jgele.19.00021

\section{Published in:}

Geotechnique Letters

\section{Citing this paper}

Please note that where the full-text provided on Manchester Research Explorer is the Author Accepted Manuscript or Proof version this may differ from the final Published version. If citing, it is advised that you check and use the publisher's definitive version.

\section{General rights}

Copyright and moral rights for the publications made accessible in the Research Explorer are retained by the authors and/or other copyright owners and it is a condition of accessing publications that users recognise and abide by the legal requirements associated with these rights.

\section{Takedown policy}

If you believe that this document breaches copyright please refer to the University of Manchester's Takedown Procedures [http://man.ac.uk/04Y6Bo] or contact uml.scholarlycommunications@manchester.ac.uk providing relevant details, so we can investigate your claim.

\section{OPEN ACCESS}


Date: 9 December 2019

Manuscript title: Small-strain stiffness degradation of artificially cemented sands.

Authors: Jorge A. Mendoza-Ulloa ${ }^{a}$, Domenico Lombardi ${ }^{b}$, Syed Mohd Ahmad. ${ }^{c}$

Affiliations: ${ }^{a} \mathrm{PhD}$ Researcher. Department of Mechanical Aerospace and Civil Engineering, The University of Manchester. ORCID 0000-0002-5756-5104. ${ }^{b}$ Lecturer in Geotechnics. Department of Mechanical Aerospace and Civil Engineering, The University of Manchester. ORCID 0000-0003-4116-8347 ${ }^{c}$ Lecturer in Geotechnics. Department of Mechanical Aerospace and Civil Engineering, The University of Manchester. ORCID 0000-0002-2570-179X

Corresponding author: Jorge A. Mendoza-Ulloa. Department of Mechanical Aerospace and Civil Engineering, The University of Manchester. 76 Sackville St, Manchester M1 3NJ. Tel.: +4407475409789

email: jorge.mendoza@postgrad.manchester.ac.uk

Number of words: 2254

Number of figures: 7

Number of tables: 3 


\title{
Small-strain stiffness degradation of artificially cemented sands
}

\author{
JORGE A. MENDOZA-ULLOA*. DOMENICO. LOMBARDI†. SYED MOHD. AHMAD†
}

\begin{abstract}
This paper investigates the degradation of small-strain stiffness of artificially cemented sand subjected to isotropic loading cycles using bender elements. Samples with cement contents of $3 \%$ and $5 \%$ were allowed to cure for 72 hours using fast setting Portland Cement under a constant confining pressure of $200 \mathrm{kPa}$. Two types of test were conducted on the samples: 'load-unload' test, where samples were subjected to increasing isotropic confining pressures and then returning to the initial pressure of $200 \mathrm{kPa}$; and 'unload-load' test, where samples were subjected to decreasing confining pressures and then taken back to the initial pressure of $200 \mathrm{kPa}$. The effect of cementation on the initial microstructure of the samples was analysed using X-Ray Computed Tomography and Scanning Electron Microscope. Cemented samples showed a clear degradation of the normalised small-strain stiffness, after a differential confining pressure was applied, suggesting that the cemented matrix is highly affected by isotropic loading cycles.
\end{abstract}

KEYWORDS: small-strain stiffness, cemented sand, bender elements, X-ray tomography, scanning electron microscope

ICE Publishing: all rights reserved

\section{INTRODUCTION}

Cementation plays a fundamental role on the mechanical behaviour of natural sediments, in particular to the stiffness of the material which is known to increase with increasing cement content addition (Chang et al. (1990); Chang \& Woods (1992); Khan et al. (2006); Lee et al. (2011); Amaral et al. (2011)). Available studies on the topic have often used artificiallycemented soils as an analogue of natural cementation owing to challenges in sampling naturally-cemented soils. Most of the available literature has focused on the stress-strain behaviour of cemented samples under deviatoric shearing, consistently showing that cementation greatly increases the strength of sands (Saxena et al. (1988); Coop \& Atkinson (1993); Airey (1993); Dvorkin \& Nur (1996); Huang \& Airey (1998); Schnaid et al. (2001); Rotta et al. (2003); Consoli et al. (2007); Dalla Rosa et al. (2008); Consoli et al. (2012)). To investigate the effects of sampling on the mechanical properties of naturally-cemented soils, the response of specimens subjected to varying levels of confinement needs to be understood and quantified. Studies focusing on the behaviour of cemented soils under isotropic loading have been limited to one load unload sequence, and the available research has often shown contradictory findings. According to Acar \& El-Tahir (1986), the small-strain stiffness, $G_{0}$, of sands with cement contents of 1,2 and $4 \%$ increased when confining pressure was

Manuscript received. .

Published online at www.geotechniqueletters.com

*PhD researcher. The University of Manchester. M13 9PL, Manchester, UK. †Lecturer in Geotechnics. The University of Manchester. M13 9PL, Manchester, UK increased from 10 to $400 \mathrm{kPa}$. In contrast, studies by Baig et al. (1997), on sand samples with cement content from 1 to $5 \%$, and Fernandez \& Santamarina (2001), on samples with $2 \%$ of cement content, concluded that $G_{0}$ of cemented soils is independent of the mean effective stress. Additionally Baig et al. (1997) reported a lower $G_{0}$ during a isotropic load-unload sequence in samples with cement content of $1 \%$ subjected to increasing confining pressure from $70 \mathrm{kPa}$ to 700 $\mathrm{kPa}$ and then reduced to $70 \mathrm{kPa}$; however samples with $2 \%$ and higher cement content did not show any degradation under the same test conditions. Fernandez \& Santamarina (2001) reported a significant reduction on $G_{0}$ when an isotropic unload - load sequence was applied to a cemented sample with $2 \%$ cement content. Sharma \& Fahey (2004) compared the $G_{0}$ of isotropically consolidated and anisotropically consolidated samples with consolidation stress ratios up to 2.5. It was concluded that the reduction in $G_{0}$ is more severe with increasing deviator stress than with increasing isotropic mean effective stress.

Yun \& Santamarina (2005) studied samples with $2 \%$ cement content subjected to $K_{o}$ one-dimensional loading and unloading and observed a decrease of shear wave velocity. With these findings it is suggested that decementation is more pronounced on unloading rather than loading of the cemented samples. A recent study conducted by Corte et al. (2019) on small-strain stiffness during unload-reload cycles at different points along the triaxial stress path showed limited cement bond degradation.

Given the previous studies, the available research suggests that the small-strain stiffness of cemented soils is sensitive 
to changes in isotropic stresses, however it has been mostly limited to one load-unload (or unload-load) stage.

The purpose of this study is to explore the evolution and degradation of the $G_{0}$ on artificially-cemented sands subjected to isotropic loading cycles with data acquired using bender elements. Special attention is given to the micro-structural analysis of artificially cemented sand, and its effect on $G_{0}$.

\section{MATERIALS}

\section{Redhill-110 sand}

A poorly-graded, fine grained sand with $98.8 \%$ silica content and commercially known as Redhill-110 was used for this research. The index properties are listed in Table 1.

\section{Fast setting Portland cement}

A fast-setting Portland cement, commercially known as No nonsense rapid-set cement, was used as a cementing agent. This cement-based material reduces the initial setting time, thus allowing shorter sample preparations. One of the main differences between fast-setting Portland Cement and Ordinary Porland cement is the presence of tretacalcium aluminate $4 \mathrm{CaO}_{3} \mathrm{Al}_{2} \mathrm{O}_{3} \mathrm{CaSO}_{4}$. This compound hydrates to form needleshaped crystals of ettringite $\mathrm{Ca}_{6} \mathrm{Al}_{2}\left(\mathrm{SO}_{4}\right)_{3}(\mathrm{OH})_{12} \cdot 26 \mathrm{H}_{2} \mathrm{O}$. This crystal develops quickly and gives strenght to rapid hardening cement.

Table 1. Index properties of Redhill-110

\begin{tabular}{ccccccc}
\hline \hline Material & $\begin{array}{c}D_{50} \\
(\mathrm{~mm})\end{array}$ & $e_{\min }$ & $e_{\max }$ & $G_{s}$ & $\begin{array}{l}\phi_{c} \\
\left({ }^{\circ}\right)\end{array}$ & $U_{c}$ \\
\hline Redhill-110 & 0.144 & 0.608 & 1.035 & 2.65 & 36 & 1.63 \\
\hline
\end{tabular}

\section{Sample preparation}

A summary of the tests performed is shown in Table 2.

As high cement content would result in very stiff and hard materials that behave more like soft rocks than soils, a cement content in the range 3 - $5 \%$ by Redhill-110 sand dry weight was chosen for the tests. Cement and sand have different specific gravities (2.65 and 3.15 respectively) thus a composite specific gravity had to be obtained for both cement contents being 2.66 for $3 \%$ cement content and 2.67 for $5 \%$ cement content. Bulk density of the samples is assumed to keep constant by not allowing samples to consolidate at any stage, however samples were not fully saturated. A sample with no cement addition was tested under the same non saturated conditions showing no increase in shear wave velocity.

The specimens (75 mm diameter x $150 \mathrm{~mm}$ height) were prepared by mixing the sand and cement in dry condition, and then mixing them manually with water for 10 minutes. Next, the cement-sand mixture was statically compacted controlling the mass and volume in 3 layers in a split mould mounted on the base of a triaxial cell to a target void ratio of 0.75 with a fixed water content of $19 \%$. Mixing and compacting was achieved within 30 minutes of initial curing time, which was less that the setting time of the fast-setting Portland cement ( 3 hours). Once the mixture was compacted into the mould and the top cap was placed, a small negative pressure was applied to the sample to remove the mould. A sample at this stage is shown in Figure 1. After the cell was filled with de-aired water and confining pressure applied the negative pressure was removed from the sample. Samples were then let to cure for 72 hours under a constant confining pressure of $200 \mathrm{kPa}$.

Table 2. Sample properties

\begin{tabular}{cccccc}
\hline \hline $\begin{array}{c}\text { Sample } \\
\text { ID }\end{array}$ & $e$ & $\rho$ & $\begin{array}{c}\text { cement } \\
\text { content } \\
(\%)\end{array}$ & $(V)$ & $(k H z)$ \\
\hline c10 & 0.76 & 1.50 & 0 & 10 & 16.6 \\
c13 & 0.74 & 1.53 & 3 & 14 & 16.6 \\
c23 & 0.73 & 1.54 & 3 & 14 & 16.6 \\
c33 & 0.74 & 1.53 & 3 & 14 & 16.6 \\
c43 & 0.74 & 1.53 & 3 & 14 & 16.6 \\
c53 & 0.77 & 1.50 & 3 & 14 & 16.6 \\
c63 & 0.75 & 1.53 & 3 & 14 & 16.6 \\
c15 & 0.78 & 1.50 & 5 & 14 & 12.5 \\
c25 & 0.76 & 1.52 & 5 & 14 & 12.5 \\
c35 & 0.77 & 1.51 & 5 & 14 & 12.5 \\
\hline
\end{tabular}

\section{Experimental set-up}

As soon as the sample was subjected to the confining pressure of $200 \mathrm{kPa}$ the change of shear wave velocity was monitored for 72 hours with bender element inserted in the pedestal and top cap using two sine waves signals with amplitude, $A$, of $14 \mathrm{~V}$ and $10 \mathrm{~V}$ for the cemented and uncemented samples, respectively. Evolution of the shear wave is shown in Figure 2. The frequency, $f$, was set to minimise the near-field effect according to frequency range recommended by SanchezSalinero et al. (1986) and Lee \& Santamarina (2005)

$$
2 \leq f \Delta t=\frac{L}{\lambda} \leq 8
$$

where $\Delta t$ is the time of propagation of the body wave from the sender and receiver, $L$ is the distance between the bender elements, and $\lambda$ is the wavelength. Details of the settings are shown in Table 2. Arrival time was estimated using crosscorrelation. After no significant increase in shear wave velocity was observed, the sample was subjected to a 'load-unload' test where isotropic confinement was increased in steps of $50 \mathrm{kPa}$ and then returned to the initial isotropic confinement pressure of $200 \mathrm{kPa}$ where the shear wave velocity was measured with bender element. Subsequent 'load-unload' cycles followed until a final maximum confining pressure of $800 \mathrm{kPa}$ was achieved. An 'unload-load' test was also conducted where the confinement pressure was decreased by steps of $50 \mathrm{kPa}$ and then increased to the initial isotropic confinement of $200 \mathrm{kPa}$ and shear wave velocity measured as in 'load-unload' test. 
Subsequent 'unload-load' cycles followed until a minimum confining pressure of $0 \mathrm{kPa}$ was achieved.

\section{RESULTS}

\section{Evolution of small-strain stiffness during setting}

The evolution of the small-strain stiffness during the setting period is presented in Figure 3. This was computed from Equation 2, where $\rho$ is the bulk density and $V_{s}$ the shear wave velocity.

$$
G_{0}=\rho V_{s}^{2}=\rho \frac{L^{2}}{\Delta t^{2}}
$$

As it can be seen from Figure 3, samples exhibited a similar initial value of $G_{0}(\sim 140 \mathrm{MPa})$ and attained a maximum value after approximately 20 hours. The sample with the highest cement content showed the greatest increase in small-strain stiffness. Results of an uncemented sample are shown as reference.

\section{Load-unload test}

The results of the samples subjected to 'load-unload' test are shown in Figure 4. These samples were subjected to 12 increases of confining pressure, $p^{\prime}$, each being $50 \mathrm{kPa}$ higher than the previous. After each increase, the sample was brought back to the initial confining pressure of $200 \mathrm{kPa}, p_{i}^{\prime}$, and the small-strain stiffness measured. $G_{0}$ was then normalised by the initial small-strain stiffness at $200 \mathrm{kPa}, G_{0-i}$. From Figure 4 it is clear that the normalised small-strain stiffness decreases with increasing confining pressure attaining a minimum value of 0.6.

\section{Unload-load test}

The results of the samples subjected to 'unload-load' test are shown in Figure 5. These samples were subjected to 4 decreases of confining pressure, $p^{\prime}$, each being $50 \mathrm{kPa}$ lower than the previous. After each decrease, the sample was brought back to the initial confining pressure of $200 \mathrm{kPa}, p_{i}^{\prime}$. The small-strain stiffness measured was normalised as in the load-unload test. As it can be seen in Figure 5, the sample showed a decrease in the normalised small-strain stiffness up to approximately 0.9 .

\section{X-Ray CT scanning and Scanning Electron Microscopy analysis}

A sample with cement content of $5 \%$ with $10 \mathrm{~mm}$ of diameter and $10 \mathrm{~mm}$ height was scanned using the High Flux Nikon XTEK bay in the Henry Moseley X-Ray Imaging Facility of The University of Manchester. Following Fonseca et al. (2013) a voxel size of $4.99 \mu \mathrm{m}$ was used to achieve a resolution of $0.33 D_{50}$. A subvolume of $8 \mathrm{~mm}^{3}$ was selected to segment three different phases that can be identified as sand, cement bond and void. The computed volumes of the phases are shown in Table 3. The void ratio is computed as 0.73 which matches the range of the void ratios of the samples tested. The spatial distribution of the different phases is shown in Figure 7. Cement

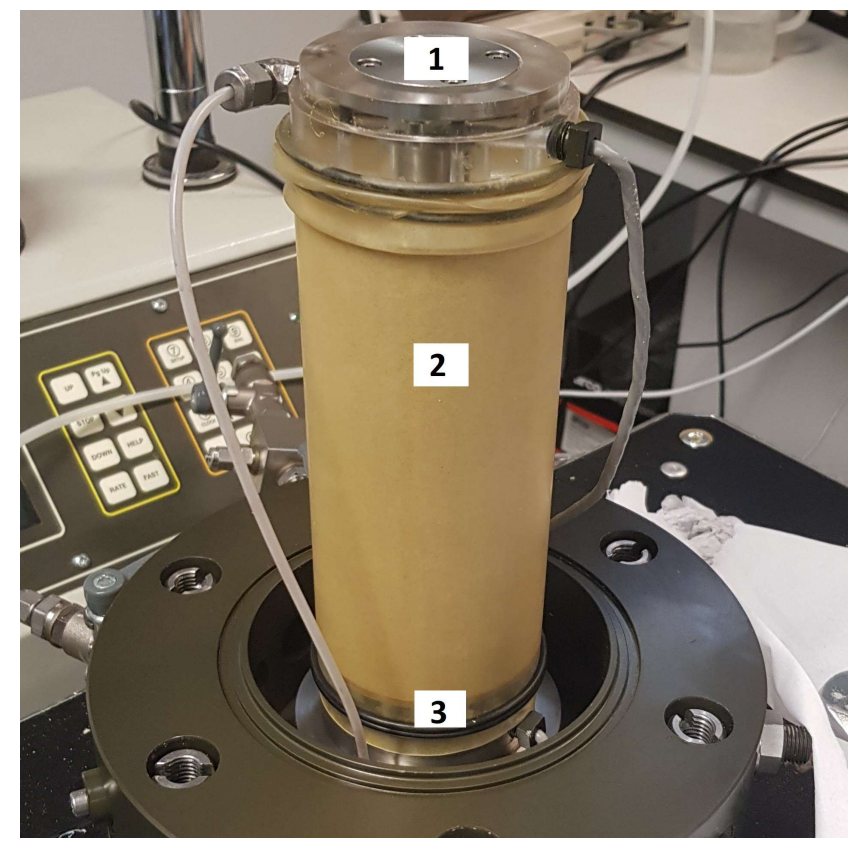

Fig. 1. Cemented sample after compaction and mould removal. 1) Top cap containing sender bender element. 2) Sample compacted. 3) Pedestal containing receiver bender element.

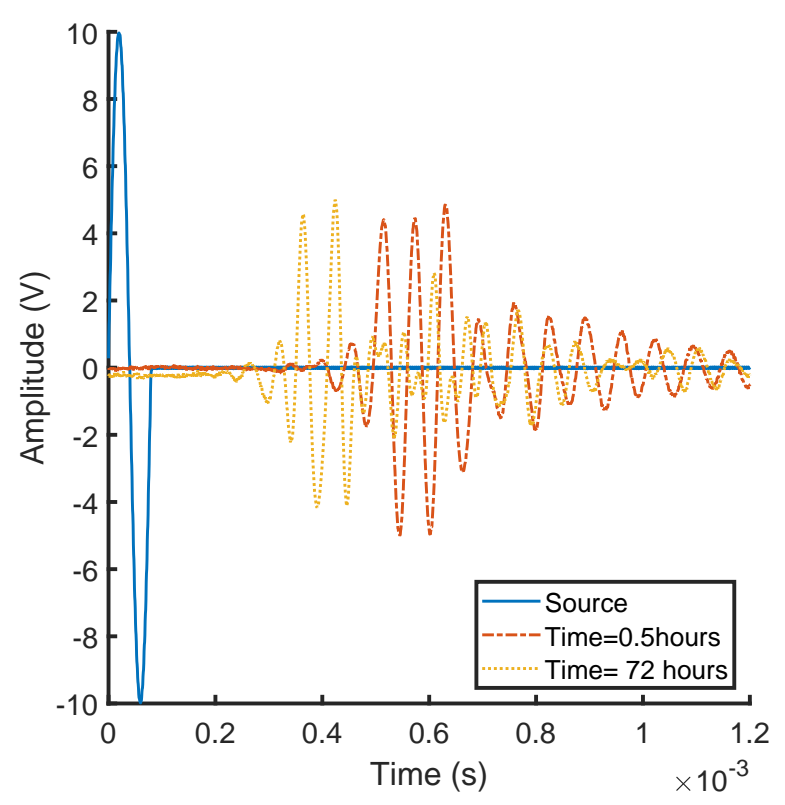

Fig. 2. Evolution of shear wave velocity at initial time and after 72 hours of curing.

bond appears scarce on the planar view but accounts for a 2 $\%$ of the total volume. To investigate the microstructure of the cement bonds a different sample of the same characteristics was scanned in the Scanning Electron Microscope, SEM, which has been previously used to analyse samples cemented with different cementing agents (Terzis et al. (2016)). Figure 6 shows that the uncemented sample grains appear with well defined edges, whereas the cemented sample shows some needle-type particles accumulated at the contact point between grains. Furthermore, the images show a needle type formation 


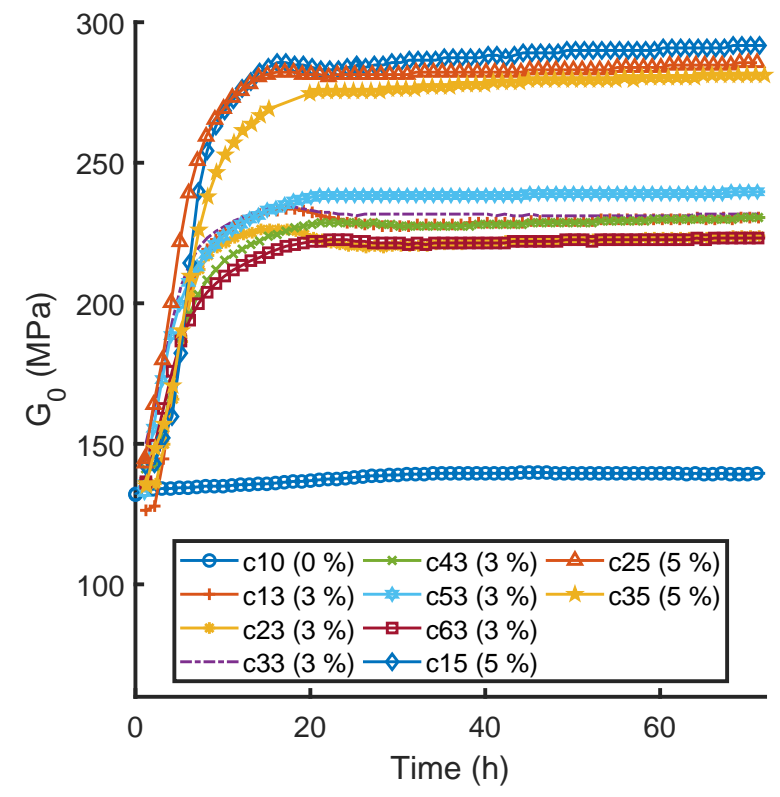

Fig. 3. Evolution of $G_{0}$ after 72 hours of curing

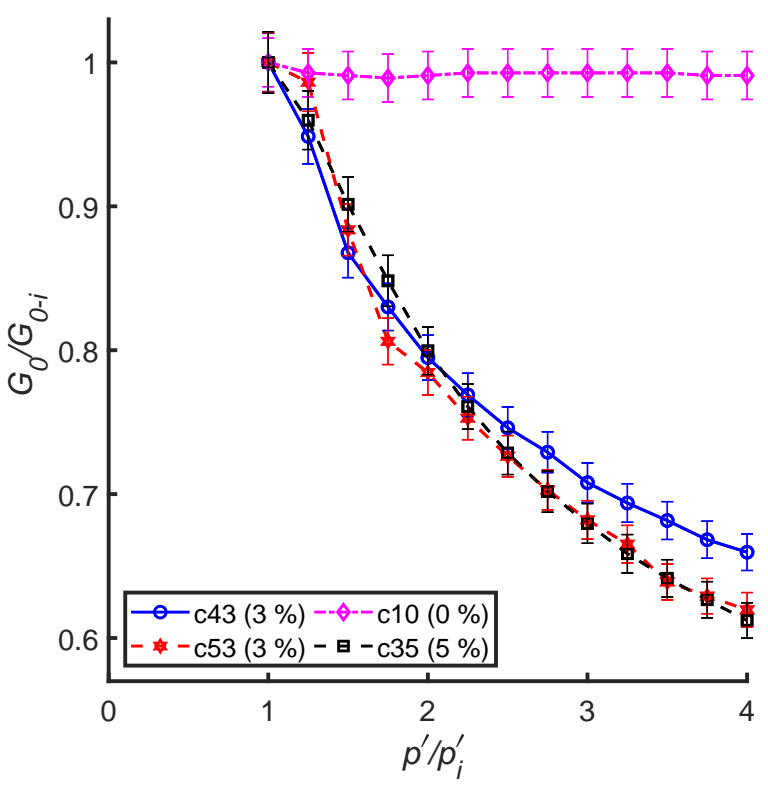

Fig. 4. $G_{0-i}$ degradation under 'load-unload' test

bonding two grains in what appears to be ettringite needles formed during the cement hydration.

Table 3. Results from the computed segmented volumes on the $3 \mathrm{D}$ reconstruction

\begin{tabular}{|c|c|c|c|}
\hline Phase & $\begin{array}{c}\text { Volume } \\
\left(\mu m^{3}\right)\end{array}$ & $\begin{array}{l}\text { Volume } \\
\left(\mathrm{mm}^{3}\right)\end{array}$ & $e$ \\
\hline sand & 4473501000 & 4.473501 & \\
\hline void & 3380490000 & 3.38049 & 0.73 \\
\hline cement & 135879000 & 0.135879 & \\
\hline
\end{tabular}

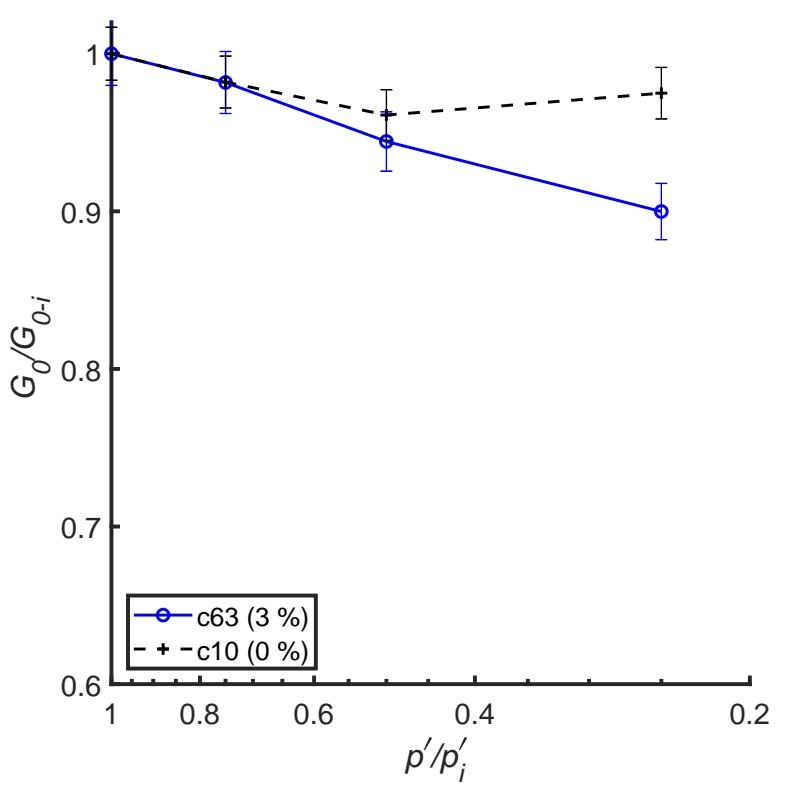

Fig. 5. $G_{0-i}$ degradation under 'unload-load' test

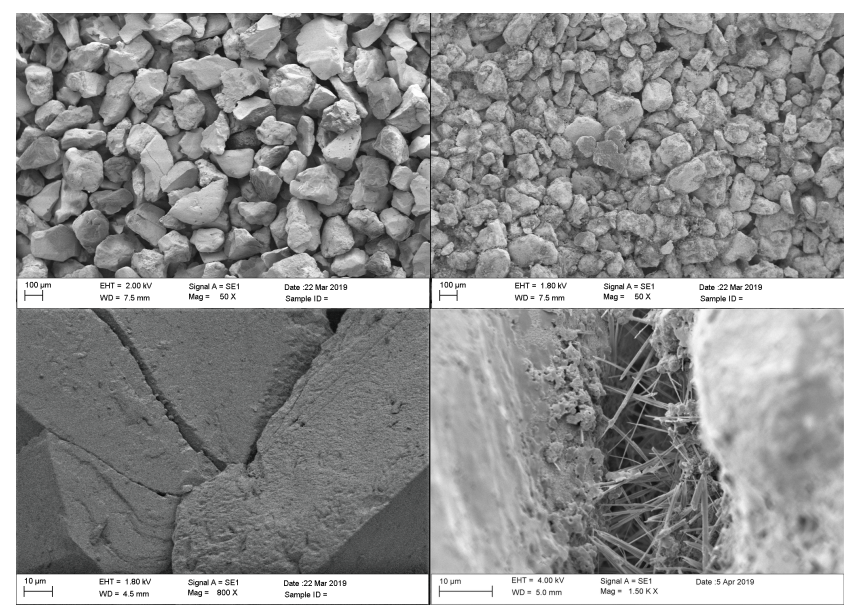

Fig. 6. Scattered electron images of uncemented and cemented samples. Top-left: General view of grains of Red-hill 110 where clear edges can be observed. Bottom-left: Contact point of two uncemented sand grains where no precipitation of particles can be seen. Top-right: General view of a cemented sample with $5 \%$ of cement content. Bottom-right: Contact point of two cemented grains where a bond created by a needle-type formation can be observed.

\section{DISCUSSION}

Using Portland cement is a convenient way to create cementation under laboratory conditions; it greatly increases the small-strain stiffness $G_{0}$ in the first 20 hours of curing. The degradation of the $G_{0}$ is evident on both 'load-unload' and 'unload-load' cases. After every cycle of increase, or decrease, in the confining pressure, the measured $G_{0}$ was lower than the initial $G_{0-i}$. As the change in $G_{0}$ of a sample without cement content addition is negligible when tested under the same condition as the other samples, it can be concluded that the degradation of $G_{0}$ is due to damage to the cement bond after the cement curing. The level of $G_{0}$ degradation imposed by the isotropic loading can be attributed to two different things 
a)

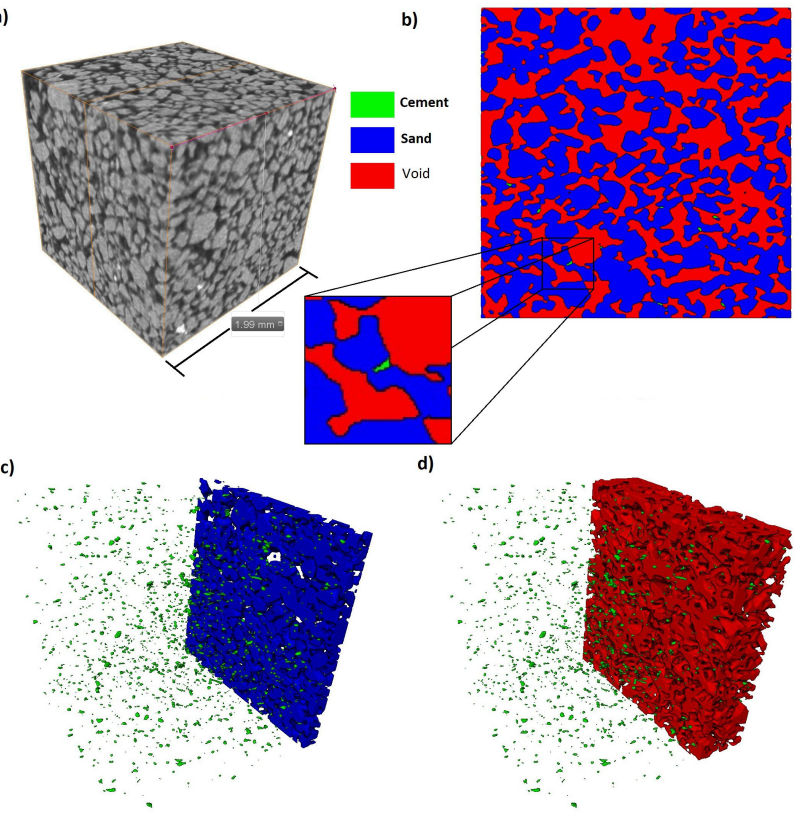

Fig. 7. Phase segmentation of a $8 \mathrm{~mm}^{3}$ of cemented sand. a) 3D reconstruction of the subvolume. b) $X Y$ plane view of segmented subvolume showing in green the cement bond, in blue the sand grains and in red the void space. c) 3D segmentation and spatial distribution of the cement bond and sand grains. d) 3D segmentation and spatial distribution of cement bonds and voids.

on the two types of test. While in the 'load-unload' test the $G_{0}$ degradation is attributed to the isotropic stress level imposed to the sample, the degradation of $G_{0}$ on the 'unload-load' test can be attributed not only to the stress level but also to the number of cycles the sample has been decompressed to a given isotropic stress. This comes from the fact that $G_{0}$ is controlled by the void ratio and confining stress according to Ishihara (1996) while Fernandez \& Santamarina (2001) has shown how for cemented soils the loading history is more relevant on unloading stages. Imaging analysis with SEM shows that the cement bonds created using fast setting Portland cement have a needle-type shape, made of ettringite, which is a common mineral formed during the early stages of cement hydration. It also shows that a cement content of $5 \%$ does not generate an uniform coating that would bond the grains together which can also be observed in the $3 \mathrm{D}$ volume reconstruction with the data from the X-Ray CT scanning. This bond type can easily be damaged when there are changes in isotropic confinement, which explains the observed results.

\section{CONCLUSIONS}

The small-strain stiffness of cemented samples showed degradation due to the increase of confining pressure. The 'unload-load' test simulated the effect of pressure release occurring on soils being extracted from the subsurface, and then tested under confining pressure. A change in isotropic confinement would damage the cement bonds as the experimental result suggest. This would be of interest on soil properties inferred from in-situ test, such as shear wave velocity when changes on the stress conditions of the soil take place (e.g excavations or landfills). However SEM analysis shows that those bonds created with Portland cement differ from the structures seen on other common natural cementing agents in soils such as calcite, which appear as a crystalline bond; silica, which appears as an overgrowth of silica grains; or iron oxide, commonly found as a rhombohedral crystal or disk-shaped hematite (Mitchell (2005)). Additional research is needed on different cementing agents to asses this effect on other microstructures. For samples cemented with Portland cement, this $G_{0}$ degradation is a phenomena that can easily be overlooked when samples are cured under atmospheric pressure and then tested in a triaxial apparatus.

\section{ACKNOWLEDGEMENTS}

This research has been funded by the Energy Secretary and the National Science Council of Mexico. The authors acknowledge the support and funding of the Henry Moseley X-Ray Imaging Facility of The University of Manchester and the Electron Microscopy Centre of The University of Manchester in the completion of this work.

\section{REFERENCES}

Acar, Y. B. \& El-Tahir, E. T. A. (1986). Low strain dynamic properties of artificially cemented sand. Journal of Geotechnical Engineering 112, No. 11, 1001-1015, doi:10.1061/(ASCE)0733-9410(1986) 112:11(1001).

Airey, D. W. (1993). Triaxial testing of naturally cemented carbonate soil. Journal of Geotechnical Engineering 119, No. 9, 1379-1398, doi:10.1061/(ASCE)0733-9410(1993)119:9(1379).

Amaral, M. F., Viana da Fonseca, A., Arroyo, M., Cascante, G. \& Carvalho, J. (2011). Compression and shear wave propagation in cemented-sand specimens. Geotechnique Letters 1, No. 3, 79-84, doi:10.1680/geolett.11.00032.

Baig, S., Picornell, M. \& Nazarian, S. (1997). Low strain shear moduli of cemented sands. Journal of Geotechnical Engineering 123, No. 6, 540-545, doi:10.1061/(ASCE)1090-0241(1997)123:6(540).

Chang, C. S., Misra, A. \& Sundaram, S. S. (1990). Micromechanical modelling of cemented sands under low amplitude oscillations. Geotechnique 40, No. 2, 251-263, doi:10.1680/geot.1990.40.2. 251.

Chang, T. \& Woods, R. D. (1992). Effect of Particle Contact Bond on Shear Modulus. Journal of Geotechnical Engineering 118, No. 8, 1216-1233, doi:10.1061/(ASCE)0733-9410(1992)118:8(1216).

Consoli, N. C., da Fonseca, A. V., Silva, S. R., Cruz, R. C. \& Fonini, A. (2012). Parameters controlling stiffness and strength of artificially cemented soils. Geotechnique 62, No. 2, 177-183, doi:10.1680/ geot.8.P.084.

Consoli, N. C., Foppa, D., Festugato, L. \& Heineck, K. S. (2007). Key parameters for strength control of artificially cemented soils. Journal of Geotechnical and Geoenvironmental Engineering 133, No. 2, 197-205, doi:10.1061/(ASCE)1090-0241(2007)133:2(197).

Coop, M. R. \& Atkinson, J. H. (1993). The mechanics of cemented carbonate sands. Géotechnique 43, No. 1, 53-67, doi:10.1680/geot. 1993.43.1.53. 
Corte, M. B., Ibraim, E., Festugato, L., Diambra, A. \& Consoli, N. C. (2019). Stiffness of lightly cemented sand under multiaxial loading. In E3S Web of Conferences, vol. 92 (Tarantino, A. \& Ibraim, E., eds.), p. 11008, doi:10.1051/e3sconf/20199211008.

Dalla Rosa, F., Consoli, N. C. \& Baudet, B. A. (2008). An experimental investigation of the behaviour of artificially cemented soil cured under stress. Geotechnique 58, No. 8, 675-679, doi:10.1680/geot. 2008.58.8.675.

Dvorkin, J. \& Nur, A. (1996). Elasticity of high-porosity sandstones: Theory for two north sea data sets. GEOPHYSICS 61, No. 5, 13631370, doi:10.1190/1.1444059.

Fernandez, A. L. \& Santamarina, J. C. (2001). Effect of cementation on the small-strain parameters of sands. Canadian Geotechnical Journal 38, No. 1, 191-199, doi:10.1139/t00-081.

Fonseca, J., Bésuelle, P. \& Viggiani, G. (2013). Micromechanisms of inelastic deformation in sandstones: An insight using x-ray microtomography. Geotechnique Letters 3, No. APRIL/JUN, 78-83, doi: 10.1680/geolett.13.034.

Huang, T. \& Airey, D. W. (1998). Properties of artificially cemented carbonate sand. Journal of Geotechnical and Geoenvironmental Engineering 124, No. 6, 492-499, doi:10.1061/(ASCE) 1090-0241(1998)124:6(492).

Ishihara, K. (1996). Soil behaviour in earthquake geotechnics. Oxford engineering science series, Clarendon Press.

Khan, Z., Majid, A., Cascante, G., Hutchinson, D. J. \& Pezeshkpour, P. (2006). Characterization of a cemented sand with the pulse-velocity method. Canadian Geotechnical Journal 43, No. 3, 294-309, doi: 10.1139/t06-008.

Lee, J.-S. \& Santamarina, J. C. (2005). Bender Elements: Performance and Signal Interpretation. Journal of Geotechnical and Geoenvironmental Engineering 131, No. 9, 1063-1070, doi:10.1061/(ASCE) 1090-0241(2005)131:9(1063).

Lee, M. J., Choo, H., Kim, J. \& Lee, W. (2011). Effect of artificial cementation on cone tip resistance and small strain shear modulus of sand. Bulletin of Engineering Geology and the Environment 70, No. 2, 193-201, doi:10.1007/s10064-010-0312-0.

Mitchell, S. K., James K. (2005). Fundamentals of soil behavior (3rd edition). John Wiley \& Sons.

Rotta, G. V., Consoli, N. C., Prietto, P. D., Coop, M. R. \& Graham, J. (2003). Isotropic yielding in an artificially cemented soil cured under stress. Geotechnique 53, No. 5, 493-501, doi:10.1680/geot. 2003.53.5.493.

Sanchez-Salinero, I., Roesset, J. M., Stokoe, I. \& Kenneth, H. (1986). Analytical studies of body wave propagation and attenuation. Technical report, TEXAS UNIV AT AUSTIN GEOTECHNICAL ENGINEERING CENTER.

Saxena, S. K., Reddy, K. R. \& Avramidis, A. S. (1988). Liquefaction resistance of artificially cemented sand. Journal of Geotechnical Engineering 114, No. 12, 1395-1413, doi:10.1061/(ASCE) 0733-9410(1988)114:12(1395).

Schnaid, F., Prietto, P. D. \& Consoli, N. C. (2001). Characterization of cemented sand in triaxial compression. Journal of Geotechnical and Geoenvironmental Engineering 127, No. 10, 857-868, doi: 10.1061/(ASCE)1090-0241(2001)127:10(857).

Sharma, S. S. \& Fahey, M. (2004). Deformation characteristics of two cemented calcareous soils. Canadian Geotechnical Journal 41, No. 6, 1139-1151, doi:10.1139/T04-066.

Terzis, D., Bernier-Latmani, R. \& Laloui, L. (2016). Fabric characteristics and mechanical response of bio-improved sand to various treatment conditions. Géotechnique Letters 6, No. 1, 5057, doi:10.1680/jgele.15.00134.

Yun, T. S. \& Santamarina, J. C. (2005). Decementation, softening, and collapse: Changes in small-strain shear stiffness in K0 loading. Journal of Geotechnical and Geoenvironmental Engineering 131, No. 3, 350-358, doi:10.1061/(ASCE)1090-0241(2005)131:3(350). 